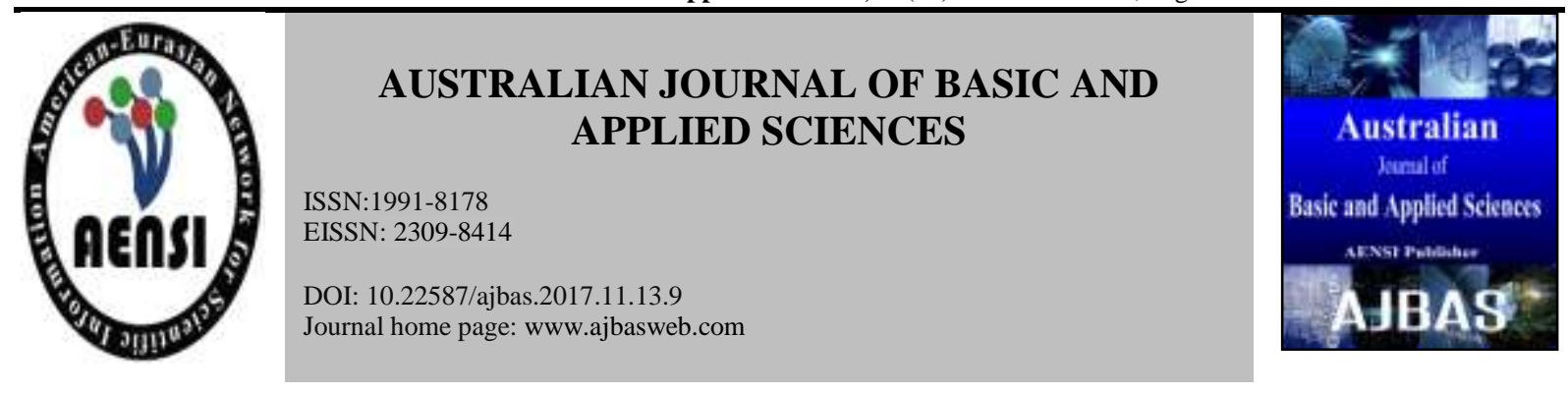

\title{
The crown efficiency of Parana-Pine
}

\author{
${ }^{1}$ Emanuel Arnoni Costa, ${ }^{1}$ César Augusto Guimarães Finger, ${ }^{1}$ Paulo Renato Schneider, ${ }^{2}$ André Felipe Hess \\ ${ }^{1}$ Federal University of Santa Maria, Department of Forest Sciences, Roraima Avenue, 1000, CEP 97105-900, Santa Maria (RS), Brazil. \\ ${ }^{2}$ Santa Catarina State University, Department of Forest Engineering, College of Agriculture and Veterinary (CAV), Luiz de Camões Avenue, \\ 2090, CEP 88520-000, Lages (SC), Brazil.
}

\section{Address For Correspondence:}

Emanuel Arnoni Costa, Federal University of Santa Maria, Department of Forest Sciences, Roraima Avenue, 1000, CEP 97105-900, Santa Maria (RS), Brazil.

E-mail: emanuelarnonicost@hotmail.com

\section{ART I CLE INFO}

\section{Article history:}

Received 19 August 2017

Accepted 1 November 2017

Available online 11 November 2017

Keywords:

Araucaria, crown dimensions, growth efficiency

\begin{abstract}
A B S T R A C T
Background: Araucaria angustifolia has high-quality wood, variability and ecological adaptation to environmental conditions. In most cases, the crown efficiency expresses the capacity of tree growth and can be described by the ratio between the increment in basal area with its crown projection area. This measure allows determining the growth capacity of each tree to be removed during a thinning. Objective: This study evaluated the crown efficiency of Araucaria angustifolia trees, according to the sociological position: dominant, codominant, dominated and open grown trees. Results: The relationship between crown efficiency and crown projection area for trees of three social positions in the forest and open growth trees shows the reduction of efficiency with the increase of crown projection area. Open grown trees are more efficient, followed by dominant, codominant and dominated. The inclusion of variable of the crown length in model of efficiency provided best values of the adjustment and accuracy, except in model the dominated trees, that did not alter in reason of the higher competition, low vigor and luminosity to which the crown is submitted. In open growth trees, the increase in value $\mathrm{R}^{2}$ was of $51.6 \%$, confirming the dependence of the variable of crown length on the explanation of the crown efficiency. Conclusion: Trees with better sociological position in stand have more efficient crown, as the crown length increases. Narrow and long crowns are more productive, grow in smaller spaces, and permit greater number of trees per area unit. For maximize the production per area unit, the forest management should be based on specific conditions of the trees. This specie needs light for its development and silvicultural activities are necessary to be conserved in nature. This research will improve silvicultural activities and economic planning of araucaria in southern Brazil.
\end{abstract}

\section{INTRODUCTION}

In southern region of Brazil, there is one of the most characteristic forest formations of the Atlantic Forest Biome, the Mixed Ombrophilous Forest (Oliveira-Filho and Fontes, 2000), also known as "Araucaria Forest" (IBGE, 2012). This forest is characterized by the presence of the Araucaria angustifolia (Bertol.) Kuntze specie that constitutes the upper stratum with a dominant character in this vegetation (Higuchi et al., 2012).

In spite of the great pressure, over the years, for the extraction of araucaria due to its qualities for wood use, the species still has a strong presence in many existing forest remnants (Kanieski et al., 2010). Thus, it is important to obtain information that allows the management of forests in a rational manner, executing plans and practices directed to the characteristics of the species.

As a result of this intense exploratory pressure in the past, araucaria was included in the official list of Brazilian flora species threatened with extinction in the vulnerable category (Brasil, 2008), and more recently in the International Union for Conservation of Nature - IUCN Red List of Threatened Species (Thomas, 2013) as

Open Access Journal

Published BY AENSI Publication

(C) 2017 AENSI Publisher All rights reserved

This work is licensed under the Creative Commons Attribution International License (CC BY).

http://creativecommons.org/licenses/by/4.0/

\section{๑) Open Access}

To Cite This Article: Emanuel Arnoni Costa, César Augusto Guimarães Finger, Paulo Renato Schneider, André Felipe Hess., The crown efficiency of Parana-Pine. Aust. J. Basic \& Appl. Sci., 11(13): 86-92, 2017 
critically endangered. Although the IUNC among other measures, recommends management and harvest of araucaria forests, the use of wood this species suffers restriction because of regional legislation.

In this sense, attributes of crown are important in many physiological processes and influence in the growth rate, in the growth of trunk diameter, in the fruit production and in the seeds, among others (Kozlowski and Pallardy, 1996). The growth depends on the light quantity absorbed in leaves, also on the efficiency of the conversion of light absorbed in biomass and allocation of photoassimilates in tissues (Binkley et al., 2013). The capture of light by a plant depends on the amount of radiation and the architectural arrangement of leaves within the crown, on a direct leaf orientation to the light sources and on the degree of shading resulting from the overlap of the leaf in a plane orthogonal to the light source (Pearcy et al., 2004).

The crown efficiency expressed by the ratio between the increase in volume of the basal area, with a crown projection area, allows to identify the least efficient trees (Sterba et al., 1993; Reid et al., 2004; Gspaltl et al., 2012), can be used to determine which trees to remove in thinnings (Sterba and Amateis, 1998). Thus, they defined the remaining trees after thinning in order to obtain the maximum efficiency of the growth space and consequently the growth of volume per hectare (O'Hara, 1988), that is infer about the growth in response to various silvicultural treatments (Waring et al., 1981). The knowledge of the efficiency of a tree is essential for the establishment of structured stands that increase the efficiency of the use of tree resources and the production at the level of stands (Gspaltl et al., 2013).

Additional information are importants for silviculture in mixed forests uneven aged with araucaria in southern Brazil, to favor larger growth trees for a same crown projection area. The analysis of this dimension according to the social position of the tree and the crown length makes it possible to select "future trees". The present study evaluated the crown efficiency of araucaria trees growing in natural forest according to social positions: dominant, codominant, dominated and open growth trees in field areas, to support the management and conservation strategies of the specie.

\section{Methodology:}

The sampling site is located in two rural properties, in the municipality of Lages, SC state $\left(27^{\circ} 48^{\prime} \mathrm{S}\right.$ and $\left.50^{\circ} 19^{\prime} \mathrm{W}\right)$, where araucaria trees were measured in competition in natural forest and open growing trees in the field area. These areas are located about $5 \mathrm{~km}$ distance between them and $30 \mathrm{~km}$ from the municipality.

The climate, according to the classification of Köppen, is subtropical humid, without dry season and with temperate summer $(\mathrm{Cfb})$. The altitude of the municipality is approximately 987 meters, with average annual temperature of $15.2^{\circ} \mathrm{C}$ and average annual precipitation of $1685.7 \mathrm{~m}$ (Alvares et al., 2013). The predominant soils in the region are Nitossolos Haplings and Humus Cambisols developed from basaltic rocks (Embrapa, 1999).

A total of 423 araucaria trees were intentionally selected. Of these, 308 trees are in the interior of the natural forest (dominant: $n=122$, codominant: $n=84$ and dominated: $n=102$ ), distributed according to the diameter classes found in the forest and the remaining group, 115 trees, was of trees that grew free, in an open field area.

In each tree, the diameter at breast height (d) was measured with diametrical tape, the height (h) and the height in the crown base (hbc) were measured with the Vertex IV hypsometer. The crown length (lc) was obtained by the difference between $\mathrm{h}$ and hbc. In addition, four crown rays were measured in open grown trees and eight in trees of the forest, from the central axis of the tree at level d, according to the cardinal points: north $(\mathrm{N})$, northeast $(\mathrm{NE})$, east $(\mathrm{E})$, southeast (SE), south (S), southwest (SW), west (W), and northwest (NW). In all trees, the crown rays were measured by an only one person to avoid possible tendencies. The crown radius mean $(\mathrm{mcr})$ of the tree was determined by the expression $(1): \mathrm{mcr}=\left[\left(\Sigma \mathrm{cr}^{2}\right) / \mathrm{k}\right]^{0.5}$. Where: $\mathrm{mcr}=$ crown radius mean, in $\mathrm{m}$; $\mathrm{cr}=$ radius of the crown according to the cardinal point, in $\mathrm{m}$; number of radius of crown, $\mathrm{k}=4$ for open grown trees; and $\mathrm{k}=8$ for trees in the forest.

The crown projection area (CPA) was calculated considering the circular shape as $-\mathrm{CPA}=\pi \cdot \mathrm{mcr}^{2}$, aiming to minimize errors in estimates (Costa et al., 2013). Social position of the tree in the forest was based on the silvicultural criterion, assessing the position in the vertical stratum of the forest, the presence of competing neighboring trees and the respective degree of exposure on crown light: dominant tree - occupied the upper stratum with high exposure of the crown to light; codominant tree - occupied the intermediate stratum with average exposure of the crown to light; and dominated tree - positioned in the lower stratum with low crown exposure to sunlight (Costa et al., 2014).

Periodic increment was determined on two rolls of increment, radially extracted at the breast height diameter, with the Pressler borer. When necessary, due to the difficulty of quantification of the increments of the trees under high competition, we returned to the field to collect two more rolls of increment of the same tree. Growth rings were measured in millimeters with Image Pro-Plus Software, recording the radial increments of each tree in the text file.

Thus, it was possible to determine, for each tree, the annual periodic increment in the basal area (PAIg) of araucarias with the expression $(2):$ PAIg $=\left(g_{-} g_{-t}\right) / t$. Where: PAIg $=$ annual periodic increment in basal area, in 
$\mathrm{cm}^{2}$.year ${ }^{-1} ; \mathrm{g}=$ basal area obtained at the end of the period, in $\mathrm{cm}^{2} ; \mathrm{g}_{-\mathrm{t}}=$ basal area obtained at the begin of the period, in $\mathrm{cm}^{2} ; \mathrm{t}=$ period of time considered in this study was five years.

To describe the relation of crown efficiency (CE) in function of CPA, it was used the allometric model in nonlinear form (3): $\mathrm{CE}=\beta_{0}$. $\mathrm{CPA}^{\beta}{ }_{1}$. Then, in model (3), it was added the variable of crown length (lc) by the expression (4): $\mathrm{CE}=\beta_{0} \cdot \mathrm{CPA}^{\beta}{ }_{1} \cdot \mathrm{lc}^{\beta}{ }_{2}$. Where: $\mathrm{CE}=(\mathrm{PAIg} / \mathrm{CPA})$, in $\mathrm{cm}^{2} \cdot \mathrm{m}^{-2} \cdot \mathrm{year}^{-1} ; \mathrm{PAIg}=$ annual periodic increment in basal area, in $\mathrm{cm}^{2}$.year ${ }^{-1} ; \mathrm{CPA}=$ crown projection area, in $\mathrm{m}^{2}$; lc $=$ crown length, in $\mathrm{m} ; \beta_{0}, \beta_{1}, \beta_{2}=$ estimated regression coefficients.

All statistical models were processed in the Statistical Analysis System - SAS version 8.0 (Sas Institute, 1999). The fitted models were evaluated according to the coefficient of determination $\left(\mathrm{R}^{2}\right)$, the root mean square error (RMSE) and graphical distribution of residues in function of the estimated values.

\section{Results:}

Trees were sampled with a range of diametric distribution, between $10.0 \mathrm{~cm}$ to $85.9 \mathrm{~cm}$ in group trees, growing in the forest, and $18.0 \mathrm{~cm}$ to $68.1 \mathrm{~cm}$, in open growth trees (Table 1). The crown length of trees in forest presented reduction of $2.9 \mathrm{~m}$, in average, when compared to trees in open field areas. Growth trees in competition show a reduction, in average, of the PAIg value of $37.4 \mathrm{~cm}^{2}$.year ${ }^{-1}$ (Table 1 ).

Table 1: Biometric characteristics of Araucaria trees

\begin{tabular}{|c|c|c|c|c|c|}
\hline Variables & Type & Minimum & Mean & Maximum & $\mathrm{VC} \%$ \\
\hline d & \multirow{6}{*}{ Forest } & 10.0 & 37.8 & 85.9 & 41.4 \\
\hline h & & 7.2 & 16.6 & 25.0 & 21.8 \\
\hline lc & & 0.6 & 4.5 & 10.7 & 42.4 \\
\hline CPA & & 4.1 & 77.3 & 404.2 & 77.8 \\
\hline PAIg & & 3.1 & 19.1 & 79.7 & 67.8 \\
\hline $\mathrm{CE}$ & & 0.0269 & 0.3719 & 1.8211 & 92.2 \\
\hline $\mathrm{d}$ & \multirow{6}{*}{ Open growth } & 18.0 & 41.6 & 68.1 & 24.9 \\
\hline h & & 7.3 & 12.5 & 18.0 & 20.9 \\
\hline lc & & 1.7 & 7.4 & 13.7 & 42.4 \\
\hline CPA & & 15.2 & 75.5 & 180.5 & 48.3 \\
\hline PAIg & & 6.6 & 56.5 & 133.8 & 54.7 \\
\hline $\mathrm{CE}$ & & 0.0621 & 0.8388 & 2.5809 & 55.0 \\
\hline
\end{tabular}

Where: $\mathrm{d}=$ diameter at breast height, in $\mathrm{cm} ; \mathrm{h}=$ total height, in $\mathrm{m}$; lc $=$ crown length, in $\mathrm{m} ; \mathrm{CPA}=$ crown projection area, in $\mathrm{m}^{2}$; PAIg $=$ annual periodic increment in basal area, in $\mathrm{cm}^{2} \cdot \mathrm{year}^{-1} ; \mathrm{CE}=(\mathrm{PAIg} / \mathrm{CPA}), \mathrm{in}^{2} \cdot \mathrm{m}^{-2}$. year ${ }^{-1} ; \mathrm{VC} \%=$ coefficient of variation.

The relationship between crown efficiency and CPA for trees of three social positions in the forest and open growth trees, fitted with the model (3) was significant, (see the statistics in Table 2), and shows the reduction of efficiency with the increase of CPA (Figure 1), where open growth trees were more efficient. The same relationship revealed that trees with a better sociological position were more efficient in sequence: dominant, codominant and dominated. This result may be associated with availability water, light, competition between trees, site conditions, among other factors that limit the growth of trees under competition. Thus, these factors act together, not only in relation to shape, size and dimensions of crown, but mainly to annual growth rates.

Table 2: Statistical models of crown efficiency estimate for Araucaria

\begin{tabular}{|c|c|c|c|c|c|c|c|}
\hline Type & & icients & Standard error & Value $\mathrm{t}$ & Prob. $>|t|$ & $\mathrm{R}^{2}$ & RMSE \\
\hline \multirow{3}{*}{ Dominant } & $\beta_{0}$ & 6.0121 & 0.7672 & 7.8 & $<0.0001$ & \multirow{3}{*}{0.647} & \multirow{3}{*}{56.6} \\
\hline & & & & & & & \\
\hline & $\beta_{1}$ & -0.6203 & 0.0370 & -16.8 & $<0.0001$ & & \\
\hline \multirow{3}{*}{ Codominant } & $\beta_{0}$ & 3.2592 & 0.5338 & 6.1 & $<0.0001$ & \multirow{3}{*}{0.570} & \multirow{3}{*}{50.6} \\
\hline & & & & & & & \\
\hline & $\beta_{1}$ & -0.5572 & 0.0517 & -10.8 & $<0.0001$ & & \\
\hline \multirow{3}{*}{ Dominated } & $\beta_{0}$ & 5.6521 & 0.5953 & 9.5 & $<0.0001$ & \multirow{3}{*}{0.780} & \multirow{3}{*}{46.1} \\
\hline & & & & & & & \\
\hline & $\beta_{1}$ & -0.8805 & 0.0404 & -21.8 & $<0.0001$ & & \\
\hline
\end{tabular}




\begin{tabular}{|c|c|c|c|c|c|c|c|}
\hline \multirow{3}{*}{ Open growth trees } & $\beta_{0}$ & 4.9421 & 1.6129 & 3.1 & 0.0027 & \multirow{3}{*}{0.192} & \multirow{3}{*}{50.4} \\
\hline & & & & & & & \\
\hline & $\beta_{1}$ & -0.4284 & 0.0816 & -5.3 & $<0.0001$ & & \\
\hline \multirow{3}{*}{ Dominant } & $\beta_{0}$ & 1.4754 & 0.2305 & 6.4 & $<0.0001$ & \multirow{3}{*}{0.825} & \multirow{3}{*}{40.0} \\
\hline & $\beta_{1}$ & -0.7683 & 0.0341 & -22.5 & $<0.0001$ & & \\
\hline & $\beta_{2}$ & 1.1412 & 0.0982 & 11.6 & $<0.0001$ & & \\
\hline \multirow{3}{*}{ Codominant } & $\beta_{0}$ & 1.9942 & 0.4182 & 4.8 & $<0.0001$ & \multirow{3}{*}{0.625} & \multirow{3}{*}{47.5} \\
\hline & $\beta_{1}$ & -0.5698 & 0.0486 & -11.7 & $<0.0001$ & & \\
\hline & $\beta_{2}$ & 0.3831 & 0.1112 & 3.5 & 0.0009 & & \\
\hline \multirow{3}{*}{ Dominated } & $\beta_{0}$ & 5.8091 & 0.6500 & 8.9 & $<0.0001$ & \multirow{3}{*}{0.781} & \multirow{3}{*}{46.3} \\
\hline & $\beta_{1}$ & -0.8758 & 0.0423 & -20.7 & $<0.0001$ & & \\
\hline & $\beta_{2}$ & -0.0425 & 0.0708 & -0.6 & 0.5497 & & \\
\hline \multirow{3}{*}{ Open growth trees } & $\beta_{0}$ & 2.1729 & 0.4393 & 5.0 & $<0.00) 1$ & \multirow{3}{*}{0.708} & \multirow{3}{*}{30.5} \\
\hline & $\beta_{1}$ & -0.7629 & 0.0581 & -13.1 & $<0.0001$ & & \\
\hline & $\beta_{2}$ & 1.1067 & 0.0965 & 11.5 & $<0.0001$ & & \\
\hline
\end{tabular}

Where: $\mathrm{CE}=$ crown efficiency, in $\mathrm{cm}^{2} \cdot \mathrm{m}^{-2} \cdot$ year $^{-1} ; \mathrm{CPA}=$ crown horizontal projection area, in $\mathrm{m}^{2} ; \mathrm{lc}=$ crown length, in $\mathrm{m} ; \mathrm{n}=$ number of trees; $\beta_{0}, \beta_{1}, \beta_{2}=$ estimated regression coefficients; Prob. $>|t|=$ Probability of significance for the value $t ; R^{2}=$ coefficient of determination; RMSE $=$ root mean square error

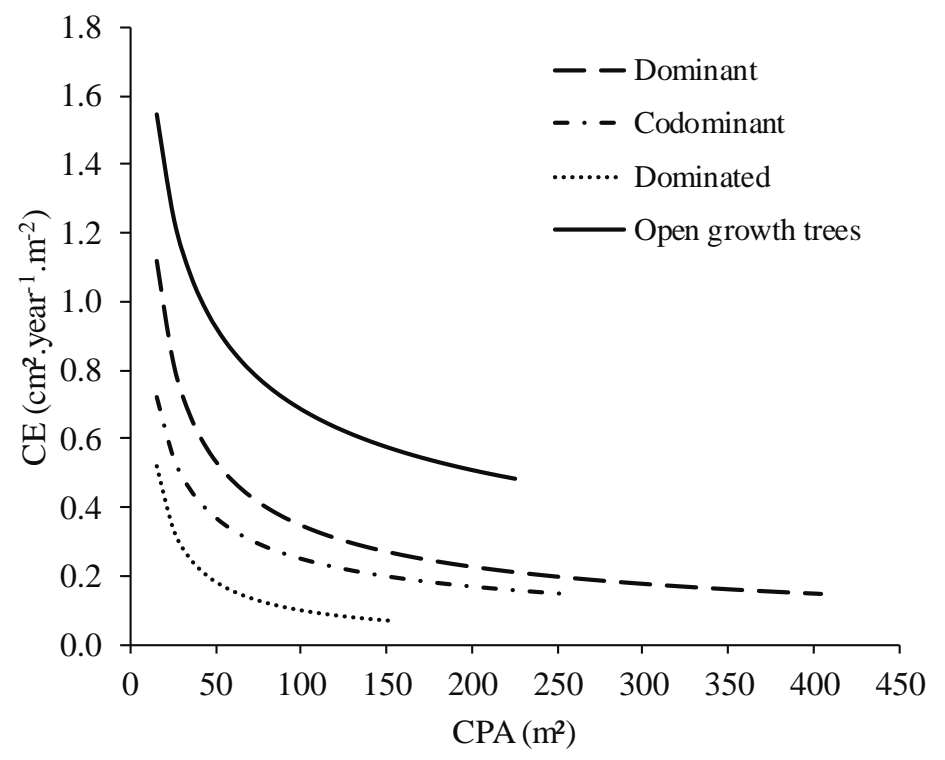

Fig. 1: Crown efficiency of Araucaria trees

The inclusion of variable of the crown length in efficiency models (Table 2), provided best values of the adjustment and accuracy, except in model the dominated trees, that did not alter in reason of the higher competition, of the low vigor and luminosity to which the crown is submitted. In open growth trees, the increase in value $\mathrm{R}^{2}$ was of $51.6 \%$, confirming the dependence of this variable on the explanation of the crown efficiency.

Curves of crown efficiency developed with fixed values: maximum, mean and minimum for the variable of crown length show increased crown efficiency in trees with higher crown length (Figure 2). This behavior was evident in open growth trees (Figure 2d), in sequence of social position dominant (Figure 2a) and codominant (Figure 2b). In dominated trees under greater competition, the effect had little influence on the crown length 
increase, with line regressions almost overlapping (Figure 2c), reflecting the low vigor of these trees in assimilation and their conversion in biomass.
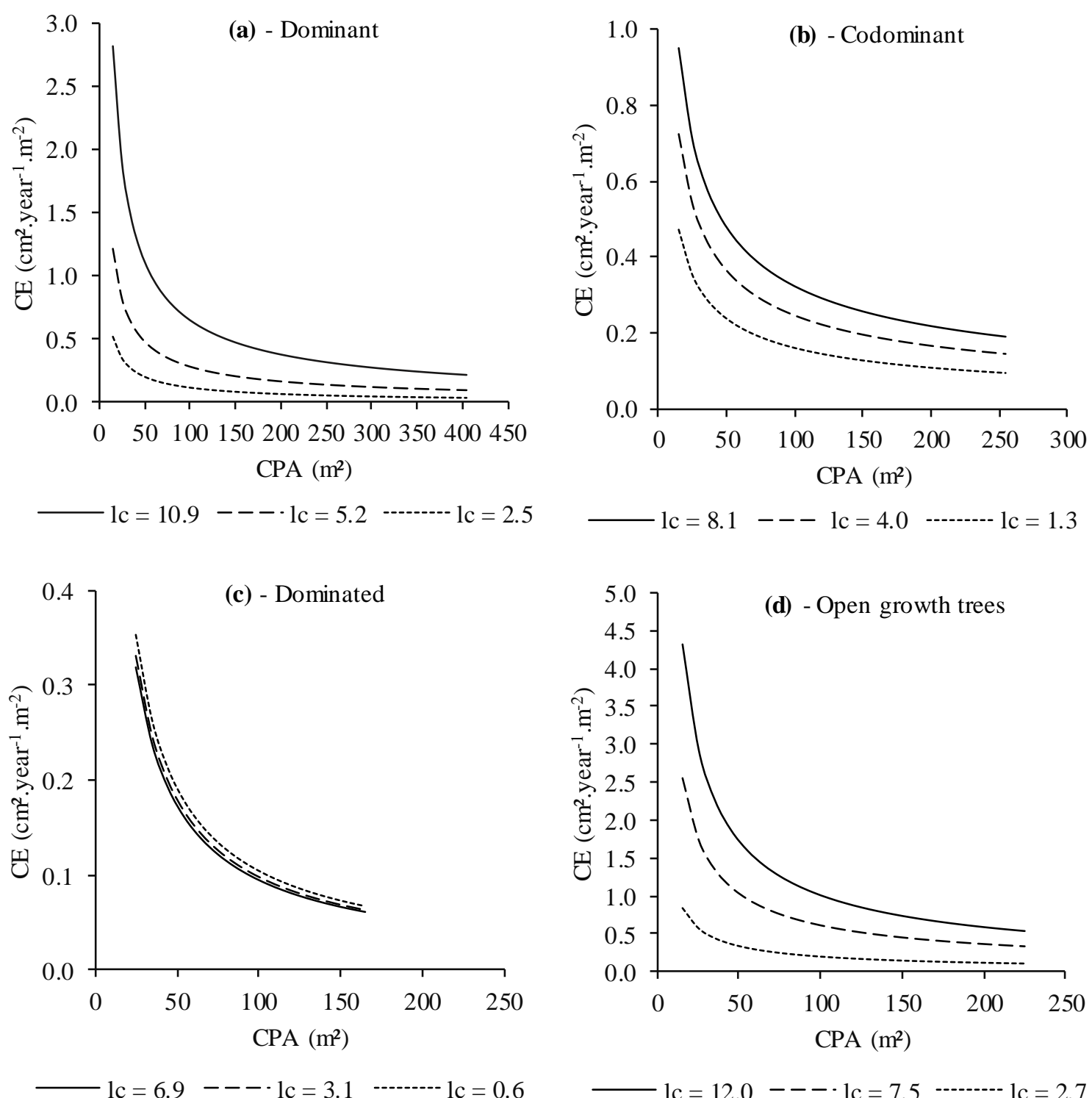

Fig. 2: Crown efficiency of araucaria trees with value: minimum, mean and maximum; with the inclusion of crown length (lc) in model, according to the social position of trees growing in the forest and open growth trees

\section{Discussion:}

For a given CPA, it occurs an increase of crown efficiency for trees of better social position, respectively, in sequence: dominant, codominant and dominated (Figure 1). Similar results were also described by Durlo (1996) and Mattos (2007) for Cedrela fissilis, Cordia trichotoma and Cabralea canjerana in the south of Brazil. Effect of the dimensional relationships of Araucaria were investigated by Costa and Finger (2017), evidencing that trees with high competition have reduced crown length and lower growth rates in diameter.

Attributes of crown are important variables used in models of mortality, growth and crown biomass of tree. Machado et al. (2015), found improvement in fit and precision of $\mathrm{h} / \mathrm{d}$ models when separating Araucaria trees in crown length classes. They also found that Araucarias with larger crown lengths tend to be taller and thicker. In another study of h/d models for Araucaria obtained improvements in the fit and accuracy when used separated groups of trees according with the social position occupied in vertical stratum of the forest and the classification in the degree exposure of the crown to light (Costa et al., 2014). 
Minatti et al. (2016), developing models of crown insertion height, crown diameter and crown proportion for araucaria, found statistically significant differences regarding the tendencies of these variables according to the sites. The same authors report that these models allow to identify the need for intervention in the forest as well as changes in the structural dynamics with different patterns in time.

Hess et al. (2016) mention that modifications of crown morphology in Araucaria are related to competition and variation in diameter breast height, which indicates that the forest management should be based on these characteristics to propose silvicultural interventions in the forest and increase the growth rates of individual trees.

\section{Conclusion:}

Crown efficiency is higher in open grown trees, followed by trees with a better social position in the forest: dominant, codominant and dominated.

The competition between trees causes clear and strong reduction of the crown. Trees with narrow and long crown have higher growth and should be preferred because they allow more trees per unit area. In order to maximize the volume per unit area, forest management must provide the specific conditions of trees.

This specie needs light for its development and silvicultural activities are necessary to be conserved in nature. This research will improve silvicultural activities and economic planning of araucaria in southern Brazil.

\section{REFERENCES}

Alvares, C.A., J.L. Stape, P.C. Sentelhas, J.L.M. Gonçalves and G. Sparovek, 2013. Köppen's climate classification map for Brazil. Meteorologische Zeitschrift, 22: 711-728.

Binkley, D., O.C. Campoe, M. Gspaltl and D.I. Forrester, 2013. Light absorption and use efficiency in forests: Why patterns differ for trees and stands. Forest Ecology and Management, 288: 5-13.

Brasil. Ministério do Meio Ambiente, 2008. Lista oficial das espécies da flora brasileira ameaçadas de extinção. Anexo I da Instrução Normativa $n^{\circ} 37$.

Costa, E.A. and C.A.G. Finger, 2017. Efeito da competição nas relações dimensionais de Araucária. Revista Floresta e Ambiente, 24: 1-11.

Costa, E.A., C.A.G. Finger and T.A. Cunha, 2013. Influência da posição social e do número de raios na estimativa da área de copa em araucária. Revista Floresta, 43(3): 429-438.

Costa, E.A., C.A.G. Finger and T.A. Cunha, 2014. Influência da posição sociológica na relação hipsométrica de Araucaria angustifolia. Revista Brasileira de Ciências Agrárias, 9: 110-116.

Durlo, M.A., 1996. Zuwachsuntersuchungen und Einzelbaumwachstums-modelle für Cabralea canjerana, cedrela fissilis und Cordia trichitima in sekundären Laubmischwälder SüdBrasiliens, Dissertation, Institut für Waldwachstumsforschung., Universität für Bodenkultur, Wien.

Embrapa, 1999. Sistema brasileiro de classificação de solos. Brasília: Embrapa Produção de Informação. Rio de Janeiro: Embrapa Solos.

Gspaltl, M., H. Sterba and K.L. O’Hara, 2012. The relationship between available area efficiency and area exploitation index in an even-aged coast redwood (Sequoia sempervirens) stand. Forestry, 85: 567-577.

Gspaltl, M., W. Bauerle, D. Binkley and H. Sterba, 2013. Leaf area and light use efficiency patterns of Norway spruce under different thinning regimes and age classes. Forest Ecology and Management, 288: 49 - 59.

Hess, A.F., T.M. Loiola, I.A. Souza and B. Nascimento, 2016. Morfometría de la copa de Araucaria angustifolia em sitios naturales em el sur de Brasil. Bosque, 37: 603-611.

Higuchi, P., A.C. Silva, T.S. Ferreira, S.T. Souza, J.P. Gomes, K.M. Silva and K.F. Santos, 2012. Floristic composition and phytogeography of the tree component of Araucaria Forest fragments in southern Brazil. Brazilian Journal of Botany, 35(2): 145-157.

Instituto Brasileiro de Geografia e Estatística (IBGE), 2012. Manual técnico da vegetação brasileira. 2ed. Manuais Técnicos em Geociências, 1. Rio de Janeiro, RJ, Brasil.

Kanieski, M.R., A.C.B. Araujo and S.J. Longhi, 2010. Quantificação da diversidade em Floresta Ombrófila Mista por meio de diferentes Índices Alfa. Scientia Forestalis, 38(88): 567-577.

Kozlowski, T.T. and S.G. Pallardy, 1996. Physiology of woody plants. 2nd ed. San Diego, Academic Press.

Machado, S.A., Y. Accioly, R.G.M. Nascimento, L.C.R Silva and C.C. Cardozo, 2015. Influência do comprimento de copa na relação hipsométrica de Araucaria angustifolia. Pesquisa Florestal Brasileira, $35: 343$ 351.

Mattos, R.B., 2007. Produtividade e incremento de Cabralea canjerana (Vell.) Mart., Cedrela fissilis Vell. e Cordia trichotoma (Vell.) Arrab. Ex Steud., em floresta nativa no Rio Grande do Sul, Tese (Doutorado em Engenharia Florestal), Universidade Federal de Santa Maria, Santa Maria.

Minatti, M., A.F. Hess, P. Ricken, T.M. Loiola and I.A Souza, 2016. Shape and size relationships of Araucaria angustifolia in South Brazil. African Journal of Agricultural Research, 11: 4121-4127. 
O’Hara, K.L., 1988. Stand structure and growing space efficiency following thinning in an even-adeg Douglas-fir stand. Canadian Journal for Forest Research, 18: 859-866.

Oliveira-Filho, A.T. and M. Fontes, 2000. Patterns of floristic differentiation among Atlantic forests in Southeastern Brazil and the influence of climate. Biotropica, 32(4): 793-810.

Pearcy, R.W., F. Valladares, S.J. Wright and E.L. Paulis, 2004. A functional analysis of the crown architecture of tropical forest Psychotria species: do species vary in light capture efficiency and consequently in carbon gain and growth?. Oecologia, 139: 163-177.

Reid, D.E.B., V.J. Lieffers and U. Silins, 2004. Growth and crown efficiency of height repressed lodgepole pine; are suppressed trees more efficient? Trees, 18: 390-398.

SAS Institute, 1999. The SAS 8.0 system for Windows. SAS Inst., Cary, NC.

Sterba, H. and R.L. Amateis, 1998. Crown efficiency in a loblolly pine (Pinus taeda) spacing experiment. Canadian Journal for Forest Research, 28: 1344-1351.

Sterba, H., F. Andrae and F. Pambudhi, 1993. Crown efficiency of oak standards as affected by mistletoe and coppice removal. Forest Ecology and Management, 62: 39-49.

Thomas P., 2013. Araucaria angustifolia. In.: International Union for Conservation of Nature (IUCN) Red List of Threatened Species.

Waring, R.H., K. Newman and J. Bell, 1981. Efficiency of Tree Crowns and Stemwood Production at Different Canopy Leaf Densities. Forestry, 54: 129-137. 